\title{
ORGANIC GEOCHEMICAL CHARACTERIZATION AND MINERALOGIC PROPERTIES OF MENGEN OIL SHALE (LUTETIAN), BOLU-TURKEY
}

\author{
I. SENGULER ${ }^{(\mathrm{a})}$, T. AYYILDIZ ${ }^{*(\mathrm{~b})}, \mathrm{Y} \mathrm{ONAL}^{(\mathrm{c})}, \mathrm{M} \mathrm{ONAL}^{(\mathrm{d})}$
}

(a) General Directorate of Mineral Research and Exploration, Energy Department 06520, Ankara, Turkey

(b) Ankara University, Faculty of Engineering, Department of Geological Engineering 06100, Ankara, Turkey

(c) Inonu University, Faculty of Engineering, Department of Chemistry Engineering Malatya, Turkey

(d) Inonu University, Faculty of Engineering, Department of Mining Engineering Malatya, Turkey

\begin{abstract}
Mengen (Bolu) basin extending northeast-southwest contains Neogene limestone, claystone, marl, lignite, and oil shale sequences. Oil shale deposit has been accumulated in shallow restricted back-platform basins during the Middle Eocene. The Middle Eocene (Lutetian) deposit divides into seven levels $L_{1-7}$. Level $L_{6}$ consists of oil shale (thickness ranging from few $\mathrm{mm}$ to 4 meters), marl, claystone and siltstone intercalations. Investigated oil shale strata of an average 50-cm thickness are green or dark brown in color. Oil shale samples contain mainly quartz, calcite, ankerite, chabazite and smectite minerals. FTIR spectra and exothermic maximum and minimum peaks of DTA and TGA weight-loss curves of oil shale samples are compatible with TOC values and mineral composition, respectively. Total organic carbon (TOC) and genetic potential (GP) values of the oil shale samples are between 1.13 and $28.32 \mathrm{wt} . \%$ and 176.11 and $281.22 \mathrm{mg} \mathrm{HC/g}$ rock, respectively. Hydrogen index (HI) and $T_{\max }$ values range from 497 to $968 \mathrm{mg} \mathrm{HC/g}$ rock and 430 to $442{ }^{\circ} \mathrm{C}$, respectively. TOC and GP values indicate a good source rock potential of this oil shale, and $T_{\max }$ values show its general immaturity. The samples stand mainly between types I and II of the evaluation path but closer to type I. This type of organic matter can generate oil upon pyrolysis.
\end{abstract}

\footnotetext{
*Corresponding author: e-mail ayyildiz@eng.ankara.edu.tr
} 


\section{Introduction}

The investigated area is located west of Mengen, which is $30 \mathrm{~km}$ northeast of Bolu (Turkey). The area is extending $14 \mathrm{~km}$. in NE-SW and $3 \mathrm{~km}$ in NWSE direction (Fig. 1). Previous studies of the basins have mainly dealt with stratigraphy, tectonics, lignite and oil shale deposits. A general geology of the study area has been presented by Uysal [1]. Cerit [2,3] has studied lithostratigraphy and tectonics of the study area. Coal geology and oil shale studies have been carried out by Lokman [4], Uysal [1,5], Erdem and Akalin [6], Senguler [7], Senguler and Ayyildiz [8]. The exploitation of oil shales represents for many countries a valuable potential source of liquid hydrocarbons and energy [9]. Turkey has a high reliance on imported energy considering the total energy used. The production of shale oil from oil shale is one of the energy generation alternatives available in Turkey, as petroleum supplies are continuously declining, accompanied by increasing costs of petroleum-based products. Therefore oil shale may present opportunities for supplying some of Turkey's fossil energy needs. There has been a lot of works about Turkish oil shale deposits whose estimated current reserve is approximately 1641 million tonnes, located mainly in four deposits Himmetoglu, Seyitomer, Hatildag and Beypazari [10]. In addition, total reserves are predicted to be 3 to 5 million tonnes [11-15]. Bituminous sediments or oil shales of mainly the Tertiary age formations in various places such as Seyitomer-Kutahya, Beypazari-Ankara, Seyitomer-Goynuk-Hatildag-Bolu, Bahcecik-Izmit, Ulukisla-Nigde and Gurun (Sivas) in Turkey have been investigated for a long time by several scientific workers [16-21].

Because of kerogen content it is a valuable source of energy as it can be converted to oil. Therefore, it is important to estimate the kerogen content and possible oil yield in an oil shale accurately. However, there has been no detailed investigation using oil shale deposits in Turkey.

Previous researches are mainly about Seyitomer, Hatildag, Goynuk and Beypazari oil shale deposits. In addition, Sari et al. [22] have discussed hydrocarbon potential of Mengen oil shale (only Gokcesu area) using TOC and pyrolysis. Nevertheless, there is no detailed information about organic geochemical, mineralogical and thermal decomposition properties on the outcropped samples from the Mengen basin in the southern part of Bolu, Turkey.

In this paper, five techniques, namely pyrolysis, XRD, DTA, FTIR and TGA, are used to characterize Mengen oil shale samples (calcerous bituminous limnic series of the Eocene age). Geochemical, mineralogical and thermal decomposition properties of Mengen oil shales are presented. 


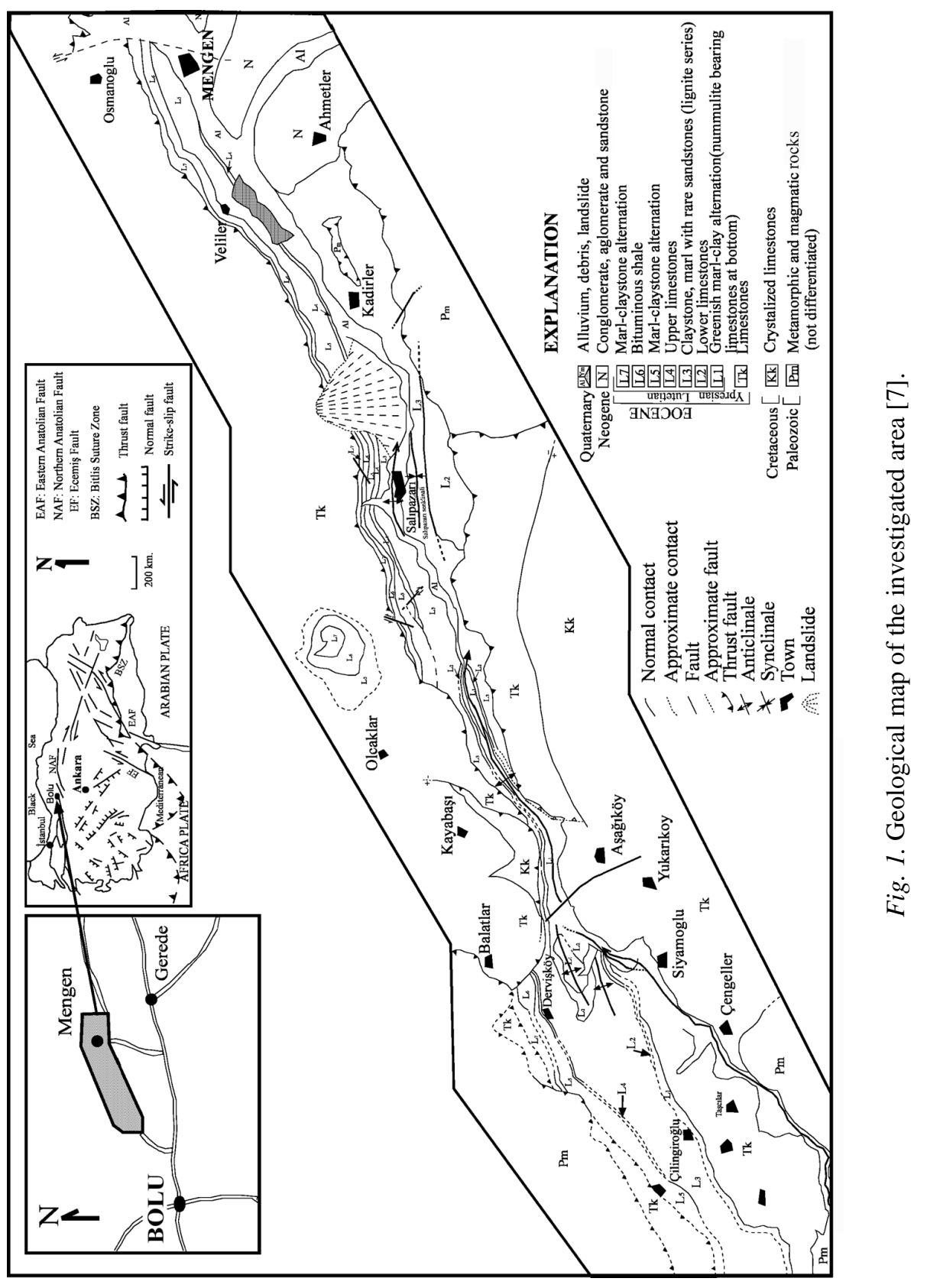




\section{Stratigraphy}

The Mengen basin (Bolu) is located in the northwest of Turkey (Fig. 1), and it occupies approximately $144 \mathrm{~km}^{2}$. The Mengen basin extending along northeast-southwest direction contains a sedimentary sequence of up to $1222 \mathrm{~m}$ in thickness [7]. The sedimentary rock sequence ranges from Silurian to Neogene [7,8]. The Paleozoic and Cretaceous basement rocks unconformably overlie the Eocene and Neogene units (Fig. 2). The Eocene unit is especially important for oil shale and divides into seven conformable levels $\mathrm{L}_{1-7}$ [7] which generally consist of clastics (marl, claystones and siltstones), calcareous oil shale, and lignite. $50 \mathrm{~m}$ thick $\mathrm{L}_{1}$ level consists of alternating green claystone, marl and limestone. Level $\mathrm{L}_{2}$ is called lower limestone with average thickness of $25 \mathrm{~m}$, and gray to beige in color. It smells badly due to bituminous impurities. Level $\mathrm{L}_{3}$, composed of graygreen and sometimes red-colored claystones and marl with limestone, is rich in lignite horizons. Its average thickness is $200 \mathrm{~m}$ and it is called the lignite series. Level $\mathrm{L}_{4}$ is the upper limestone level, differing from the lower part by lithologic properties. Its average thickness is $40 \mathrm{~m}$. Level $\mathrm{L}_{5}$ consists of alternating marl and claystone layers and contains some bituminous shale (100 $\mathrm{m}$ in thickness). Level $\mathrm{L}_{6}$ is rich in bituminous shale alternated with marl, claystone and siltstone. This level occupies a $5-\mathrm{km}^{2}$ area in the Mengen basin (Fig. 1). Like $\mathrm{L}_{5}, \mathrm{~L}_{7}$ level is composed of alternating marl and claystones, and its average thickness is $40 \mathrm{~m}$. The Neogene unit is composed mainly of conglomerates, agglomerates and sandstones.

\section{Material and methods}

\section{Oil shale samples}

The oil shale samples used in this work were collected from the Mengen basin northeast of Bolu $(30 \mathrm{~km})$ (Fig. 1). The samples were crushed to a particle size $<60$ mesh and prepared according to ASTM Standard. Mengen oil shale layers vary in thickness from few $\mathrm{mm}$ to $4 \mathrm{~m}$ are grey to dark brown in appearance, medium hard and compact, brittle and thinly laminated.

\section{Major and minor element analysis of oil shale}

Major and minor elements present in Mengen oil shale samples were analyzed by ICP at Ankara University. Eleven samples of oil shale were analyzed for major, minor and a few rare earth element content.

\section{Organic geochemical analysis}

The quantity of organic matter in the shale samples was evaluated from the total organic carbon (TOC) content and Rock-Eval 6 pyrolysis data (Turkish 


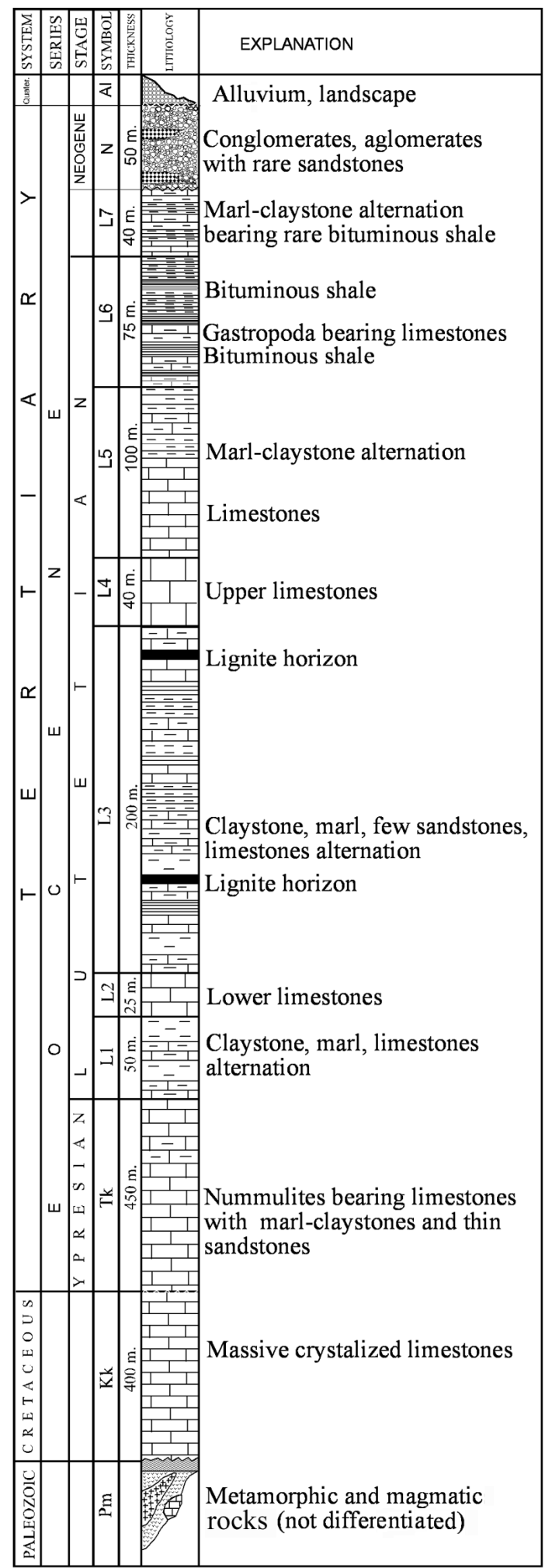


Petroleum Research Center, Ankara). The hydrogen index HI ( $\left.\mathrm{S}_{2} / \mathrm{TOC}\right)$ and the oxygen index OI $\left(\mathrm{S}_{3} / \mathrm{TOC}\right)$ were used to characterize kerogen types. A plot of these indices in the van Krevelen diagram shows the type of organic matter present in the oil shale samples. Production index $\mathrm{S}_{1} /\left(\mathrm{S}_{1}+\mathrm{S}_{2}\right)$ and $T_{\max }$ were used to characterize the amount of oil generated from the source, but one ought to consider migration and maturity of kerogen, respectively.

\section{$\mathrm{X}$-ray diffractometer analysis}

XRD analysis was carried out using a RadB X-Ray diffractometer system (scanning speed $1 \%$ min between 2 and $602 \theta$ intervals).

\section{Thermal analysis}

Differential thermal analysis (DTA) and thermogravimetry (TGA) were performed with Shimdzu, DTA-50 and TGA-50 thermal analyzers, respectively. The DTA measurements proceeded at a heating rate of $10{ }^{\circ} \mathrm{C} / \mathrm{min}$ in air (air flow rate of $20 \mathrm{ml} / \mathrm{min}$ ), whereas the TGA measurement proceeded at a heating rate of $10{ }^{\circ} \mathrm{C} / \mathrm{min}$ under nitrogen (nitrogen flow rate of $50 \mathrm{ml} / \mathrm{min}$ ).

\section{FTIR analysis}

FTIR analysis was performed at Perkin Elmer Model Spectrum one system between 650 and $4000 \mathrm{~cm}^{-1}$.

\section{Results and discussion}

The data on major-minor element analysis of Mengen oil shales are listed in Table 1a, b. The arithmetic mean of $\mathrm{SiO}_{2}$ content is $27.3 \%, \mathrm{Na}_{2} \mathrm{O}$ and $\mathrm{SiO}_{2}$ content reaches $2.09 \%$ and $34.11 \%$, respectively. $\mathrm{CaO}$ content ranges from $6.22 \%$ to $21.09 \%$ with a $15 \%$ mean value, and $\mathrm{Sr}, \mathrm{Ba}, \mathrm{Ni}, \mathrm{Cu}, \mathrm{Zn}, \mathrm{Zr}$ and $\mathrm{Rb}$ (ppm) values exceed those of other trace elements (Table 1a, b). High $\mathrm{Sr}$ values could be originated from basement marine limestones (limestones of the Cretaceous and Ypresian age). Also, these results were compared with the data on Hatildag (Miocene) and world average oil shale (Fig. 3). The content of major elements in Mengen and Hatıldağ oil shales of the Miocene is similar, however, there are some differences in the content of $\mathrm{CaO}, \mathrm{Na}_{2} \mathrm{O}$ and $\mathrm{SiO}_{2}$. As for minor elements, the oil shales from the two fields differ very much in concentration of copper, strontium, zinc, rubidium, zirconium, molybdenum, nickel, and niobium.

\section{Organic geochemical investigation}

The Eocene (Lutetian) oil shale levels have been investigated with respect to organic geochemical characteristics. 15 sections were measured and selected 11 samples were analyzed (Table 2). The samples for analysis were taken from the locations Sarikizlar (SK series) and Yukarimehmetler village (MN 


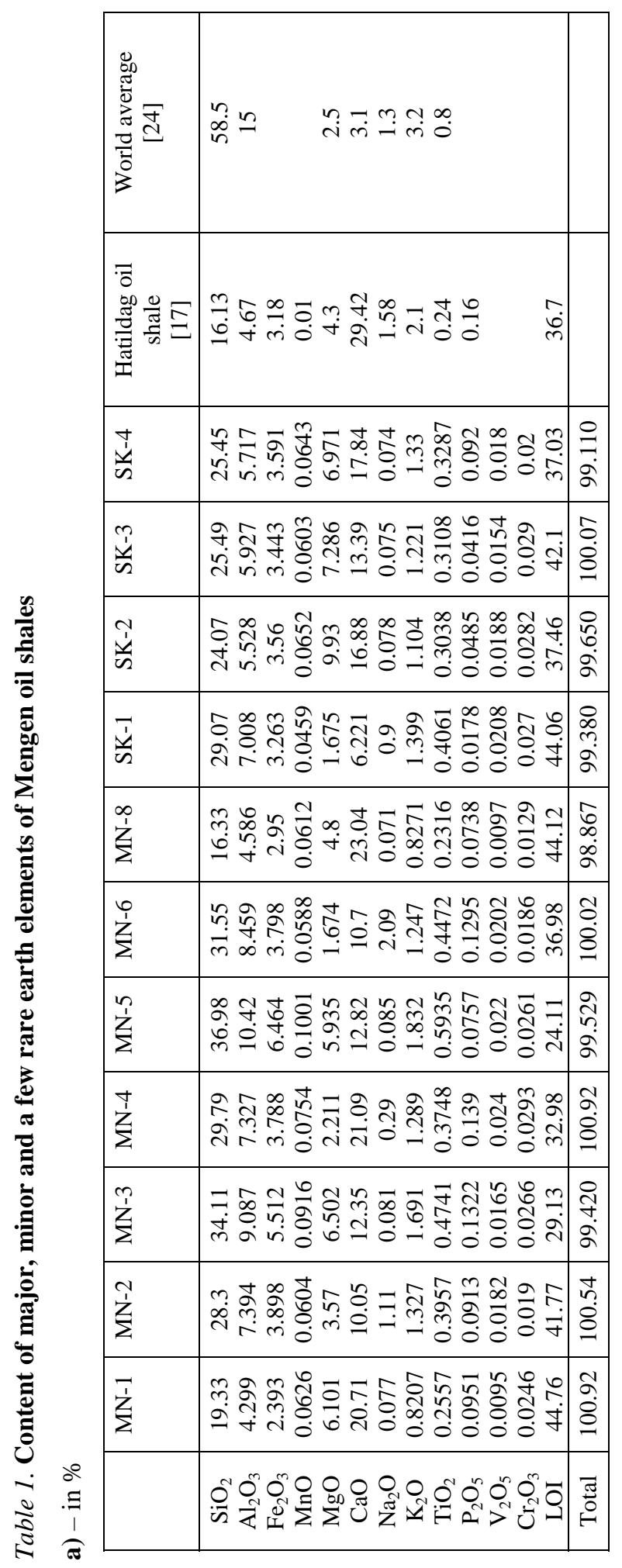




\begin{tabular}{|c|c|}
\hline 8 & 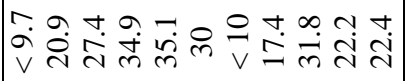 \\
\hline$\exists$ & 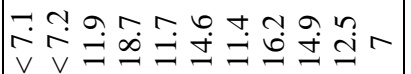 \\
\hline 2 & 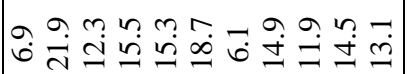 \\
\hline$\tilde{n}$ & 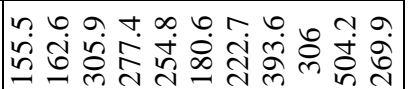 \\
\hline 3 & 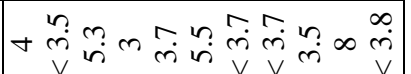 \\
\hline$\tilde{n}$ & 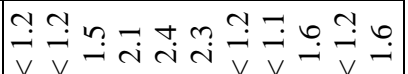 \\
\hline$\stackrel{0}{2}$ & 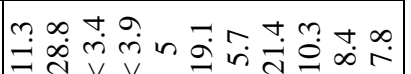 \\
\hline 之 & 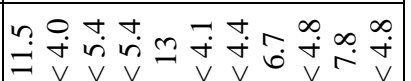 \\
\hline$\dot{s}$ & 守 \\
\hline$\succ$ & 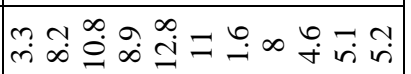 \\
\hline$\dot{s}$ & 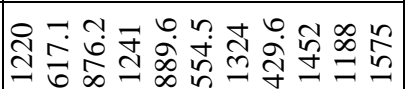 \\
\hline$\hat{\approx}$ & 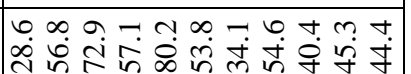 \\
\hline$\overline{0}$ & \# \\
\hline 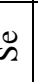 & 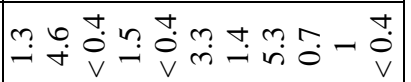 \\
\hline 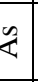 & 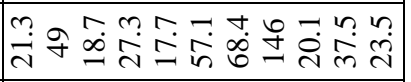 \\
\hline 8 & 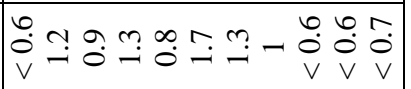 \\
\hline$\Xi$ & 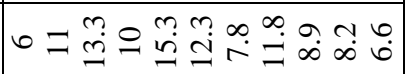 \\
\hline sี & 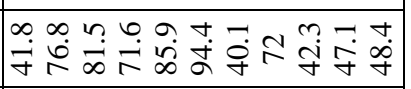 \\
\hline$z$ & 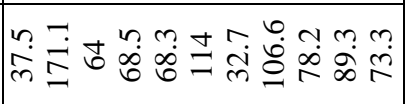 \\
\hline $\bar{z}$ & 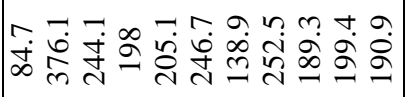 \\
\hline ¿ & 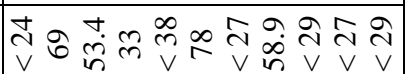 \\
\hline & 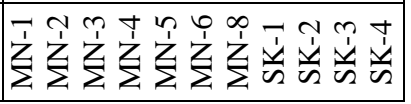 \\
\hline
\end{tabular}




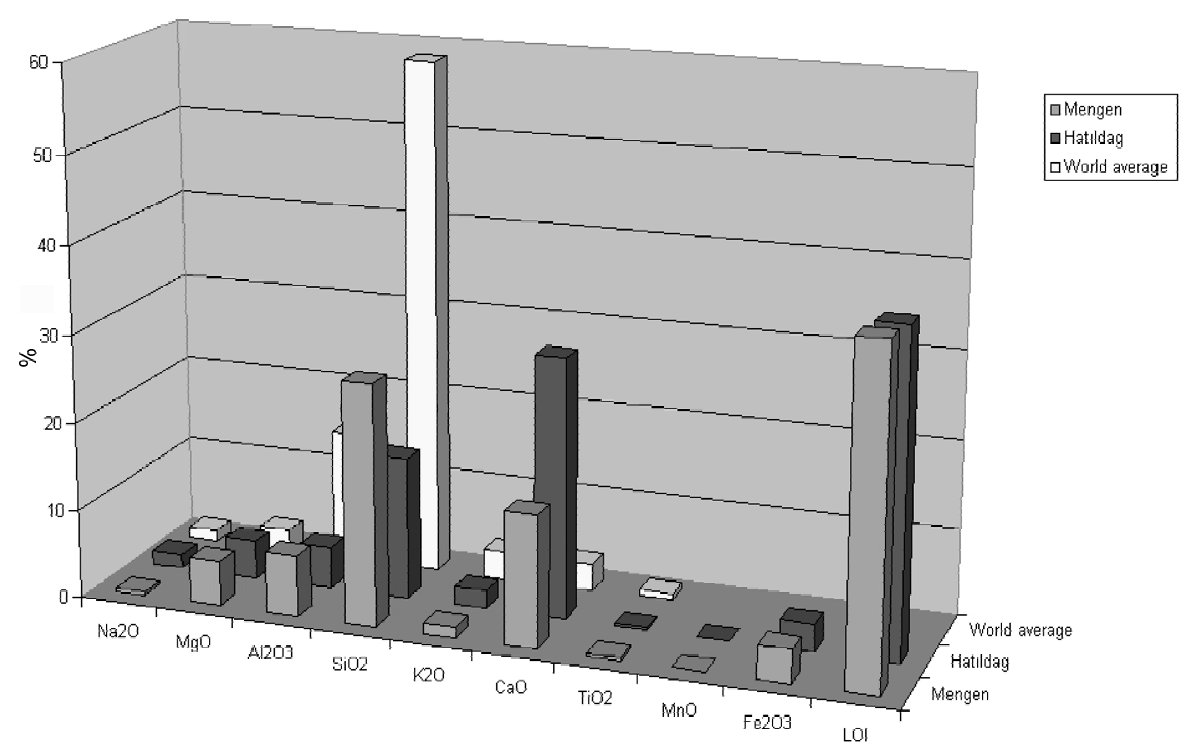

Fig. 3. Comparative diagram of Mengen and Hatildag oil shales and world average.

Table 2. Pyrolysis results of Mengen oil shales samples

\begin{tabular}{|l|c|c|c|c|c|c|c|c|}
\hline $\begin{array}{c}\text { Sample } \\
\text { number }\end{array}$ & TOC, $\%$ & $\mathrm{~S}_{1}$ & $\mathrm{~S}_{2}$ & $\mathrm{~S}_{3}$ & $\mathrm{~T}_{\max },{ }^{\circ} \mathrm{C}$ & $\mathrm{HI}$ & OI & PI \\
\hline MN-01 & 19.04 & 3.56 & 172.55 & 1.63 & 442 & 906 & 8 & 0.02 \\
$\mathrm{MN}-02$ & 8.24 & 2.98 & 58.65 & 3.04 & 439 & 711 & 36 & 0.05 \\
$\mathrm{MN}-03$ & 2.38 & 0.77 & 10.68 & 0.98 & 433 & 448 & 41 & 0.07 \\
$\mathrm{MN}-04$ & 5.61 & 1.59 & 43.86 & 1.38 & 432 & 781 & 24 & 0.03 \\
$\mathrm{MN}-05$ & 0.89 & 0.26 & 2.31 & 0.69 & 431 & 259 & 77 & 0.10 \\
$\mathrm{MN}-06$ & 12.31 & 5.55 & 86.07 & 3.89 & 430 & 699 & 31 & 0.06 \\
$\mathrm{MN}-07$ & 16.74 & 6.40 & 128.82 & 5.06 & 442 & 769 & 30 & 0.05 \\
$\mathrm{MN}-08$ & 14.95 & 2.60 & 118.00 & 5.27 & 442 & 789 & 35 & 0.02 \\
SK-01 & 28.32 & 6.17 & 274.30 & 1.70 & 442 & 968 & 6 & 0.02 \\
SK-02 & 15.48 & 3.22 & 132.46 & 1.51 & 437 & 855 & 9 & 0.02 \\
SK-03 & 12.95 & 4.96 & 99.56 & 3.66 & 436 & 768 & 28 & 0.05 \\
SK-04 & 14.71 & 5.49 & 115.89 & 3.47 & 432 & 787 & 23 & 0.05 \\
SK-05 & 1.13 & 0.31 & 5.62 & 0.72 & 438 & 497 & 63 & 0.05 \\
SK-06 & 15.59 & 8.28 & 11.03 & 4.48 & 423 & 712 & 28 & 0.07 \\
\hline
\end{tabular}

series). Two samples of them (MN-5 and SK-5) were collected from clayey facies from sections. Rock-Eval analysis was performed to determine petroleum potential and type of organic matter [23].

\section{Total organic carbon (TOC)}

Total organic carbon (TOC wt.\%.) was determined for 13 samples using a Rock-Eval 6. The results are given in Table 2. TOC content of the Sarikizlar samples ranges from 1.13 to $28.32 \mathrm{wt} . \%$. TOC content of clayey facies in the $\mathrm{L}_{5}$ level is lowest. In the Yukarimehmetler location, TOC content of the 
samples ranges from 0.89 to $19.04 \mathrm{wt} . \%$ and the average is $10.02 \mathrm{wt} . \%$. Except of clayey facies, all samples show that organic matter content in the section is high.

\section{Rock-Eval pyrolysis and organic matter types}

The analysis data were interpretated according to Espitalié et al. [23]. In the Sarikizlar samples, the HI ranges from 497 to $968 \mathrm{mg} \mathrm{HC} \mathrm{g}^{-1}$ TOC, with an average of $775 \mathrm{mg} \mathrm{HC} \mathrm{g}^{-1} \mathrm{TOC}$, and the OI ranges from 6 to $63 \mathrm{mg} \mathrm{CO}_{2} \mathrm{~g}^{-1}$ TOC, with an average of $26 \mathrm{mg} \mathrm{CO}_{2} \mathrm{~g}^{-1}$ TOC. The production index (PI) ranges from 0.02 to 0.05 , with an average of 0.038 , and $T_{\max }$ ranges from 438 to $442{ }^{\circ} \mathrm{C}$, with an average $437^{\circ} \mathrm{C}$. The organic geochemical results of the samples were plotted in the HI $v s$. $\mathrm{T}_{\max }$ and the $\mathrm{HI} v s$. OI diagrams to evaluate kerogen type. The results indicate that organic material of the samples is dominantly kerogen type I and II (Fig. 4a, b). Hydrocarbon-generating potential is estimated by measuring total pyrolytic hydrocarbon yield $\left(S_{1}+S_{2}\right)$. The pyrolysis analyses show that genetic potential values $\left(\mathrm{S}_{1}+\mathrm{S}_{2}\right)$ exceed $2 \mathrm{mg} \mathrm{HC} / \mathrm{g}$ rock, ranging between 5.93 and $280.47 \mathrm{mg} \mathrm{HC} / \mathrm{g}$ rock (Table 2).

As for level $\mathrm{L}_{5}$ of the Yukarımehmetler section, Rock-Eval analyses were made on 8 selected samples. HI values are as high as those for the Sarikizlar samples - between 259 and $906 \mathrm{mg} \mathrm{HC} \mathrm{g}^{-1}$ TOC. The production index (PI) ranges from 0.02 to 0.07 , except $\mathrm{MN}-5$ (0.10). $T_{\max }$ values range between 430 and $442{ }^{\circ} \mathrm{C}$ with an average of $436{ }^{\circ} \mathrm{C}$. Genetic potential values exceed $2 \mathrm{mg} \mathrm{HC} / \mathrm{g}$ rock, ranging between 2.57 and $176.11 \mathrm{mg} \mathrm{HC} / \mathrm{g}$ rock (Table 2). The lowest values were observed in clayey facies $(2.57 \mathrm{mg} \mathrm{HC} / \mathrm{g}$ rock). $S_{1}+S_{2}$ values for analyzed samples indicate a well to excellent source rock potential in the investigated area. The HI vs. $T_{\max }$ and HI $v s$. OI diagrams show that the samples locate along mainly on the curves of type I and II kerogen (Fig. 4a, b).

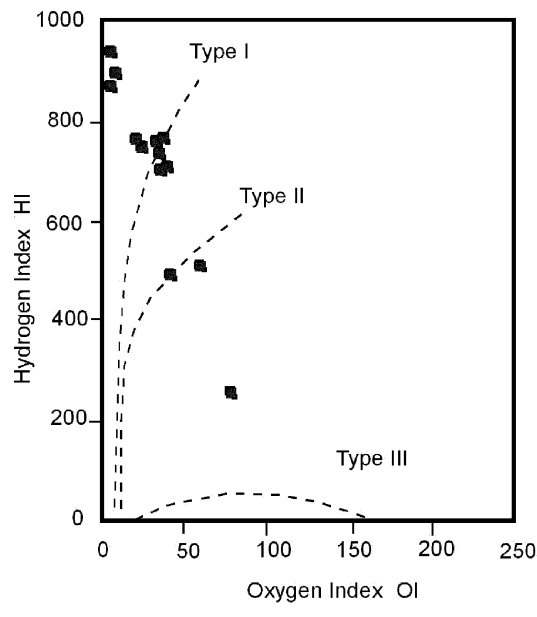

(a)

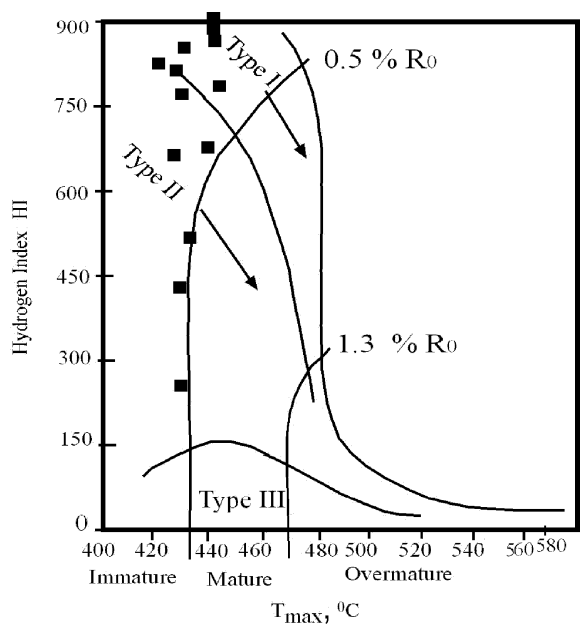

(b)

Fig. 4. Modified van Krevelen diagram of Mengen oil shale [23]. 
Kerogen was isolated from the rock matrix using standard palynological preparation procedures. Petrographically, the investigated samples are dominated by amorphous, algal, and herbaceous in oil shale facies, however, minor woody and coaly organic matter were observed in clayey facies. According to the organic matter classification of Jones [25], three main organic facies types were recognized as $\mathrm{A}, \mathrm{AB}$ and minor $\mathrm{B}$.

In terms of thermal maturity, both the temperature at maximum $S_{2}$ peak $\left(T_{\max }\right)$ and transformation ratio (PI) are generally lower than $435{ }^{\circ} \mathrm{C}$ and 0.1 expected for a mature shale (Table 2). Samples are plotted within the immature zone in Figs. 4 and 5. The Mengen oil shale samples with high GP appear immature presently but have the potential to generate both oil and gas under pyrolysis.

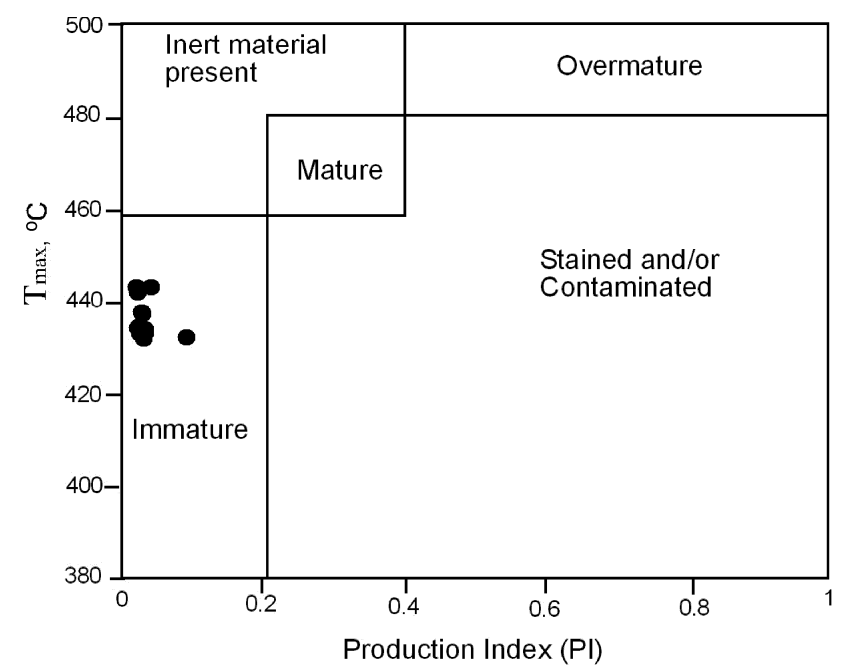

Fig. 5. Plots of $\mathrm{T}_{\max }\left({ }^{\circ} \mathrm{C}\right)$ against Production Index (PI) for Mengen oil shales.

\section{Mineralogical and thermal decomposition properties of Mengen oil shales}

XRD data of the samples in Fig. 6 show that samples SK 1 to 4 are composed of generally quartz, calcite ankerite, zeolite (chabazite), feldspar and smectite. However, samples MN-2, 5 and 7 from the MN series contain ankerite and quartz-calcite as main and accessory minerals, respectively. Also smectite (d: $14.6 \AA$ ) was determined in these samples. Nevertheless, calcite is accompanied with quartz, quartz-ankerite and ankerite in MN samples $4,6,8$ being the main mineral in sample 1 . Another mineral smectite is visible in the XRD. It loses the moisture below $200{ }^{\circ} \mathrm{C}$ and crystalline water at a much higher temperature. High TOC values of the samples containing smectite are an expected result. The results of those samples (SK-1 to 4) support that opinion. It is a case similar to MN series samples. 


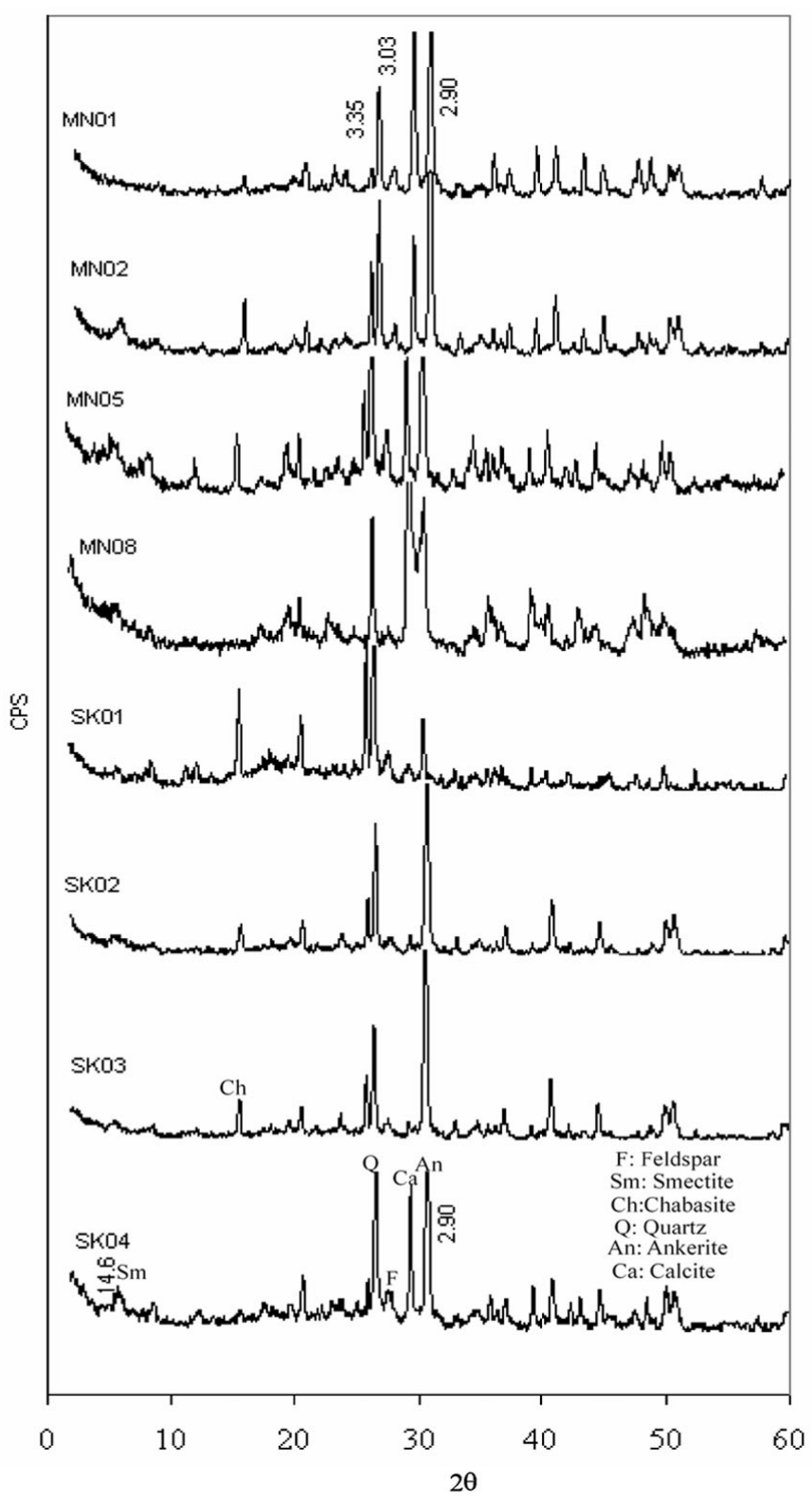

Fig. 6. XRD patterns of the investigated Mengen oil shale samples.

Calcite concentration of all samples is compatible with $S_{3}$ values presented in Table 1. Therefore, it is an expected situation that the samples containing less calcite (MN-05 and 03) have lower $\mathrm{S}_{3}$, and those with high calcite concentration (MN-4 and 06) have high $\mathrm{S}_{3}$ values. ICP analysis results are compatible with mineral composition. Ankerite samples $\mathrm{MN}-2$ and 6 are characterized with especially high $\mathrm{Fe}_{2} \mathrm{O}_{3}$ values $(6.464 \%$ and $5.512 \%$ ) (Table 1a). 
FTIR spectra of the samples are shown in Fig 7. Observing the C-H structure of all samples, 2922 and $2852 \mathrm{~cm}^{-1}$ bands in Fig. 7 are compatible with TOC values. Those bands are invisible in the spectrum of the sample

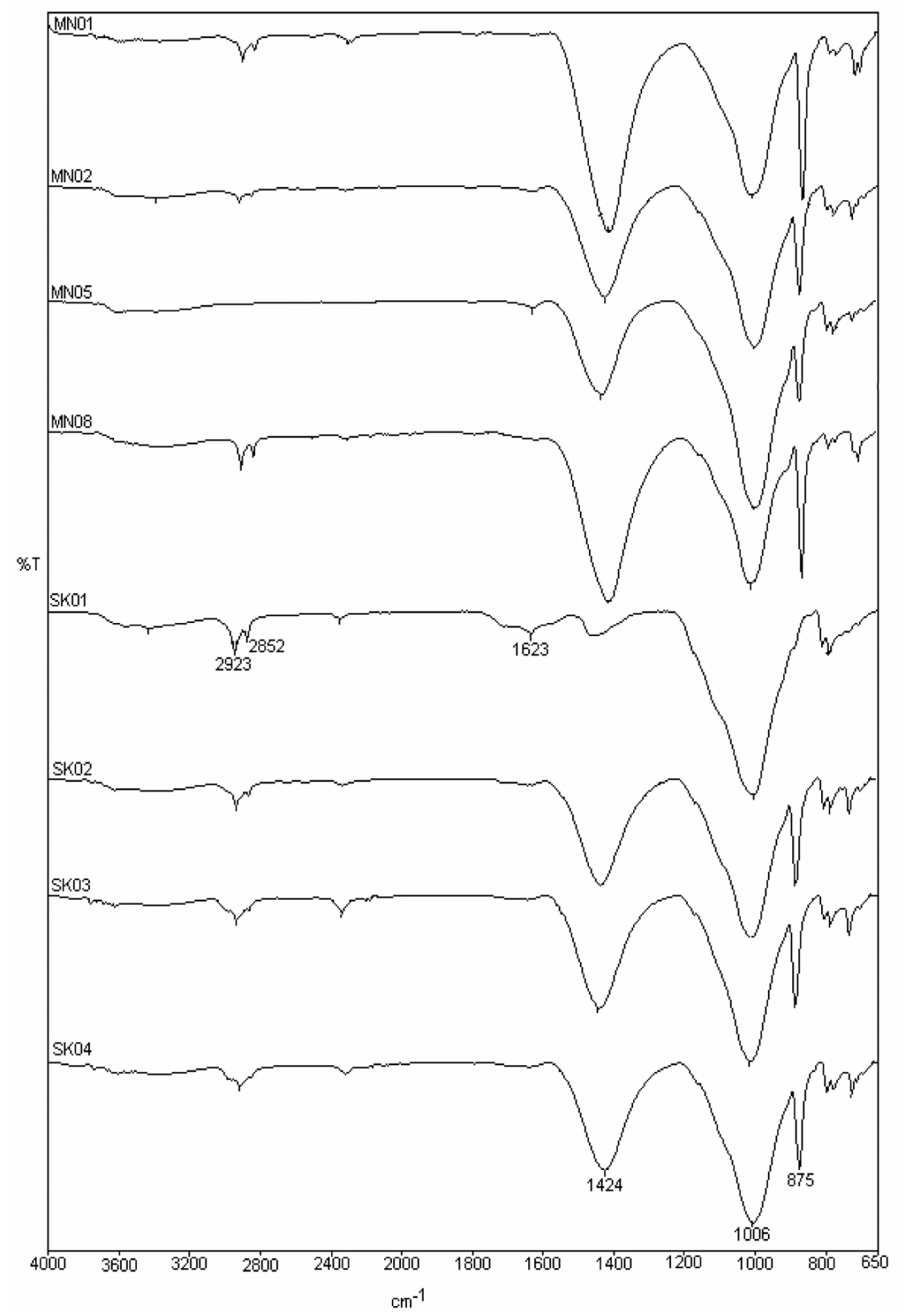

Fig. 7. FTIR curves of Mengen oil shale samples. 
with the lowest TOC value (MN-5); they are visible in the spectrum of SK-1 samples. The 1410-1437 $\mathrm{cm}^{-1}$ band observable in the spectra of all samples belongs to $\mathrm{CaCO}_{3}$ and is compatible with mineral composition. In addition, a wide and sharp band at $1000 \mathrm{~cm}^{-1}$ belongs to Si-O-M structures. The range $3200-3600 \mathrm{~cm}^{-1}$ observed in all samples belongs to $\mathrm{H}_{2} \mathrm{O}$ next to $\mathrm{OH}$ and aromatic $\mathrm{CH}$ structures. A wide and shallow band output hinders the band of aromatics. A sharp severe band at $875 \mathrm{~cm}^{-1}$ belongs to C-H structures connected to the outer ring of benzene derivative compounds in some samples of high TOC values.

TGA data of the samples are shown in Fig. 8. Weight loss curves of all samples are compatible with the content of organic and mineral compounds. For example, while weight loss of SK-1 with the highest TOC value is totally $45 \%$, that of the sample with the lowest TOC value (MN-5) is $20 \%$. In addition, there is a relationship between the increase in final pyrolysis temperature and increase in weight loss. Samples characterized by high $\mathrm{T}_{\max }$ values show an increase in the rate of weight loss. A similar relationship has also been reported by Dogan and Uysal [21]. Clay minerals such as smectite can also lose their structural water in the temperature interval $200-600{ }^{\circ} \mathrm{C}$. High clay mineral content of some samples explains why there are such deviations in weight loss values within the above temperature interval. Figure 8 shows that the highest weight loss occurs in the region of 450$550{ }^{\circ} \mathrm{C}$. All samples show a proportional relationship between the weight loss in this temperature region and the total weight loss. The next major phase of weight loss occurs in the temperature range from 600 to $850^{\circ} \mathrm{C}$. In this temperature interval, mainly carbonate minerals such as calcite, dolomite

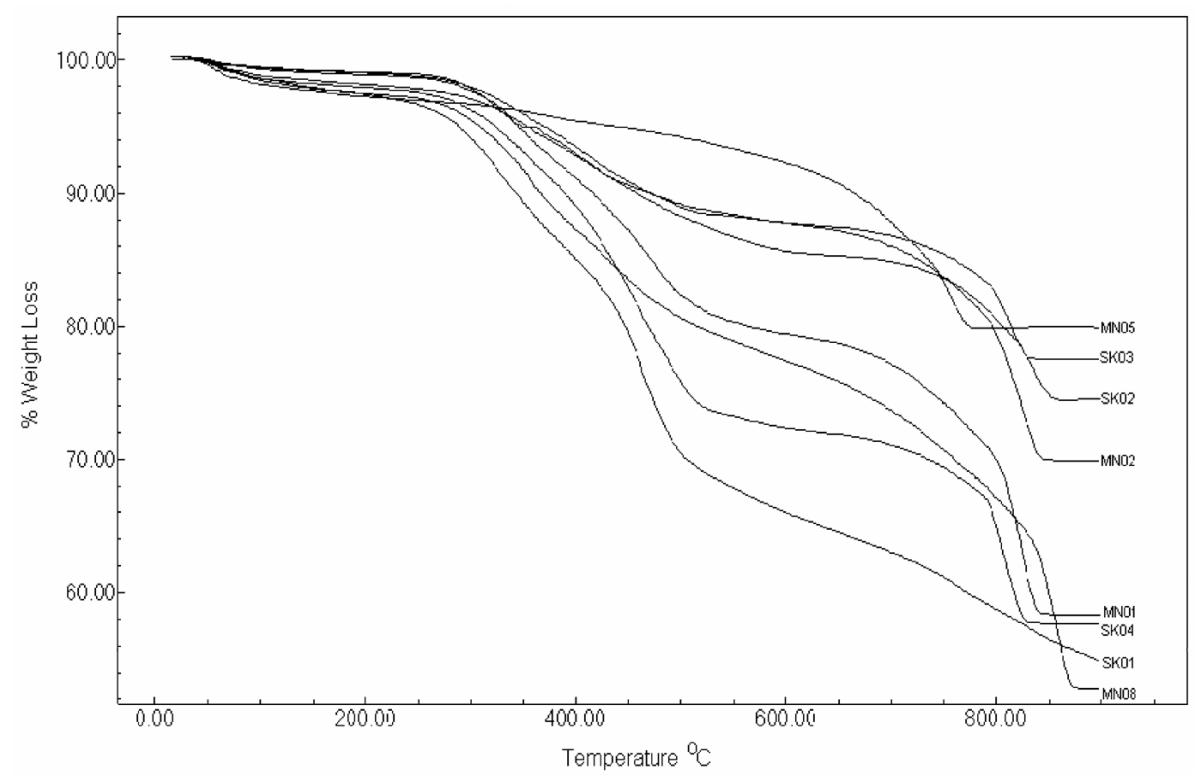

Fig. 8. TGA curves of Mengen oil shale samples. 
and ankerite decompose. Relatively high weight losses in the temperature intervals of $650-750$ and over $750{ }^{\circ} \mathrm{C}$ indicate a high calcite content.

DTA data of the samples are shown in Fig. 9. Maximum and wide of exothermic peaks are compatible with TOC content of all samples. Wideness and different alteration temperature of the exothermic peaks indicate that samples contain different organic compounds. High alteration temperature values are related to aromatic hydrocarbon structure, indicating the formation of big molecules of organic nature. Alteration temperature for sample SK-1 with high TOC value is $671{ }^{\circ} \mathrm{C}$, pointing at its compact aromatic structure. As a matter of fact, high $\mathrm{S}_{1}$ and $\mathrm{S}_{2}$ values of that sample support this conclusion. Wide exothermic peaks explain that the basic organic structure is composed of several groups. Endothermic peaks of different range between 751 and $825^{\circ} \mathrm{C}$ in all samples belong to decomposition of calcite minerals whose content in samples is different.

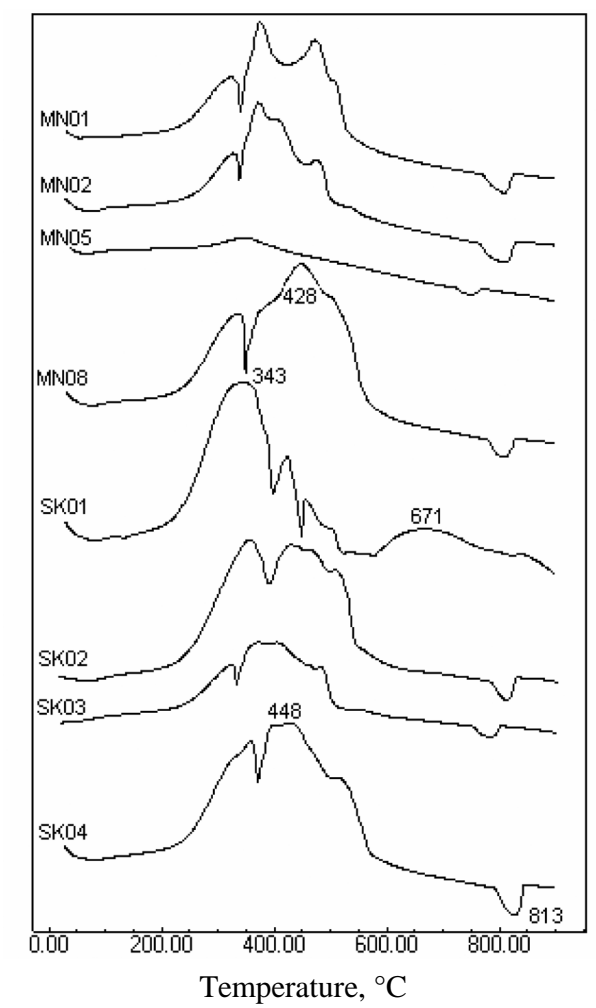

Fig. 9. DTA curves of Mengen oil shale samples.

\section{Conclusions}

The Mengen oil shale deposit is one of the big areas of Turkey's energy potential. However, there has been no detailed study about it. In this paper, geo- 
chemical, mineralogical and thermal decomposition properties of Mengent oil shale are presented. According to XRD analysis, shale samples are composed mainly of quartz, calcite, ankerite, and chabazite - smectite minerals. The TOC and GP values of samples indicate that they have a good source rock potential. However, $\mathrm{T}_{\max }$ values of samples show that shale samples are generally immature and stand mainly between types I and II of evaluation path, but closer to type I. This type of organic matter can generate oil upon pyrolysis. DTA and TOC values of Mengen oil shale samples are compatible with each other. Samples MN-1 and SK-1 with highest TOC values demonstrate the widest alteration peaks. TGA results show that the shapes of decomposition curves depend on mineral and organic composition of oil shale samples.

\section{Acknowledgements}

The authors are grateful to Assoc. Prof. Dr. Y. K. Kadioglu and Ass. Assoc. Prof. Dr. Z. Karakas (Ankara University, Faculty of Engineering, Department of Geological Engineering) for making ICP analyses and XRD determination, respectively.

\section{REFERENCES}

1. Uysal, $H$. Geology of Bolu-Merkesler area and its lignite possibilities // MTA Ens. Bulletin. 1959. Vol. 52, No. 1. P. 107-115 [in Turkish with English abstract].

2. Cerit, O. Geological investigation of Mengen (Northeastern of Bolu) region I; Lithostratigrahic units // Journal of the Earth Sciences Application and Research Centre of Hacettepe University. 1984. Vol. 11, No. 1. P. 75-89 [in Turkish with English abstract].

3. Cerit, $O$. Geological investigation of Mengen (Bolu) II: Tectonic and geological evolution // Journal of the Earth Sciences Application and Research Centre of Hacettepe University. 1985. Vol. 12, No. 1. P. 93-101 [in Turkish with English abstract].

4. Lokman, $K$. Bituminous schist of Bolu (Mengen) // MTA report number: 264, Ankara, 1929 (unpublished) [in Turkish with English abstract].

5. Uysal, H. Geological study of the lignite field of Salipazari-Mengen region (BoluNorthwest Turkey) // Symposium on Coal CENTO. December 1961, Zonguldak-Turkey, P. 149-150.

6. Erdem, I. Akalin, L. Report of (Bolu) Mengen-Salipazar1-Merkesler coal basin // MTA Report number: 7421, Ankara, 1983 (unpublished) [in Turkish with English abstract].

7. Senguler, I. Geology of Mengen (Bolu) bituminous shale area and its economical utulization possibilities // MTA Report number: 8460, 1988 (unpublished) [in Turkish with English abstract].

8. Senguler, I., Ayyildiz, T. Organic geochemical properties and economic potential of the Mengen oil shale deposits, Lutetian, Mengen-Bolu // Turkey International 
Earth Sciences Colloquium on the Aegean Regions - IESCA, Izmir, Turkey, 2005. P. 113.

9. Russel, P. L. Oil shales of the world, their origin, occurrence and exploitation. Oxford: Pergamon Press, 1990.

10. Senguler, I. Oil shale // Energy Bulletin of Turkey. 1994. Vol. 1, No. 1. P. 21-26 [in Turkish with English abstract].

11. Altun, N. E., Hicyilmaz, C., Hwang, J.-Y., Bagci, A. S., Kok, M. V. Oil shales in the world and Turkey; reserves, current situation and future prospects: a review // Oil Shale. 2006. Vol. 23, No. 3. P. 211-227.

12. Kok, M. V. Evaluation of Turkish oil shales - thermal analysis approach // Oil Shale. 2001. Vol. 18, No. 2. P. 131-138.

13. Kok, $M$. V. Thermal investigation of Seyitomer oil shale // Thermochim. Acta. 2001. Vol. 369, No. 1-2. P. 149-155.

14. Kok, M. V. Oil Shale: pyrolysis, combustion, and environment: A review // Energy Sources. 2002. Vol. 24, No. 2. P. 135-143.

15. Kök, M. V. Oil shale resources in Turkey// Oil Shale. 2006. Vol. 23, No. 3. P. 209-210.

16. Sener, M., Gundogdu, M. N. Geochemical and petrographic investigation of Himmetoglu oil shale field, Goynuk, Turkey // Fuel. 1996. Vol. 75, No. 11. P. 1313-1322.

17. Sener, M., Senguler, I. Geological, mineralogical, geochemical characteristics of oil shale bearing deposits in the Hatıldag oil shale field, Goynuk, Turkey // Fuel. 1998. Vol. 77, No. 8. P. 871-880.

18. Onal, M., Ayyildiz, T., Onal, Y., Akmil-Basar, C. Stratigraphic, mineralogical and geochemical characterization of Gurun oil shales, Central Anatolia, Turkey // Oil Shale. 2006. Vol. 23, No. 4. P. 297-312.

19. Olukcu, N., Yanik, J., Saglam, M., Yuksel, M. Liquefaction of Beypazarı oil shale by pyrolysis // J. Anal. Appl. Pyrol. 2002. Vol. 64, No. 1. P. 29-41.

20. Ozcelik, $O$. Organic geochemical characteristics of Miocene bituminous units, North of Beypazarı (Ankara) // Geology Bulletin of Turkey. 2002. Vol. 45, No. 1. P. 1-17 [in Turkish with English abstract].

21. Dogan, M. O., Uysal, B.Z. Non-isothermal pyrolysis kinetics of three Turkish oil shales // Fuel. 1996. Vol. 75, No. 12. P. 1424-1428.

22. Sari, A., Uzmez, B., Aliyev, $S$, A. Hydrocarbon potential of the bituminous shales around Mengen (Bolu) // İst. Univ. Muh. Fak. Yerbilimleri Dergisi. 2004. Vol. 17, No. 2. P. 91-102 [in Turkish with English abstract].

23. Espitalié, J. Laporte, J. L., Madec, M., Marquis, F., Leplat, P., Paulet, J., Boutefeu, A. Méthode rapide de caractérisation des roches mères, de leur potentiel pétrolier et de leur degré d'évolution // Rev. Inst. Fr. Pet. 1977. Vol. 32. P. 23-42.

24. Turekian, K. K. Wadepohl, K. H. Distribution of the elements in some major units of the Earth's Crust // Geol. Soc. Am. Bull. 1961. Vol. 72. P. 175-192.

25. Jones, R. W. Organic facies // Advances in Petroleum Geochemistry / J. Brooks, D. Welte (eds.). London: Academic Press, 1987. Vol. 2. P. 1-9.

Presented by M. V. Kök

Received November 26, 2007 